\title{
27-0xygenation of $C_{27}$-sterols and 25-hydroxylation of vitamin $D_{3}$ in kidney: cloning, structure and expression of pig kidney CYP27A
}

\author{
Hans POSTLIND, Fardin HOSSEINPOUR, Maria NORLIN and Kjell WIKVALL ${ }^{1}$ \\ Division of Biochemistry, Department of Pharmaceutical Biosciences, University of Uppsala, Box 578, S-751 23 Uppsala, Sweden
}

This paper describes the molecular cloning of a cytochrome $\mathrm{P} 450$ enzyme in pig kidney that catalyses the hydroxylations of vitamin $\mathrm{D}_{3}$ (cholecalciferol) and $\mathrm{C}_{27}$-sterols. DNA sequence analysis of the cDNA revealed that the enzyme belongs to the CYP27 family. The first 36 amino acids have many hallmarks of a mitochondrial signal sequence. The mature pig kidney CYP27 protein contains 498 amino acids. The $M_{\mathrm{r}}$ of the mature protein was calculated to be 56607. The structure of pig kidney CYP27, as deduced by DNA sequence analysis, shows $77-83 \%$ identity with CYP27A in rat, rabbit and human liver. Transfection of the renal CYP27A cDNA into simian COS cells resulted in the synthesis of an enzyme that catalysed the 25-hydroxylation of vitamin $\mathrm{D}_{3}$ and the 27 -hydroxylation of $5 \beta$-cholestane- $3 \alpha, 7 \alpha, 12 \alpha$ triol, and the further oxidation of the product into the cor- responding $\mathrm{C}_{27}$-acid $3 \alpha, 7 \alpha, 12 \alpha$-trihydroxy- $5 \beta$-cholestanoic acid. As part of these studies, the enzymic activities of cultured human embryonic kidney cells were examined using vitamin $\mathrm{D}_{3}$ and $\mathrm{C}_{27^{-}}$ sterols as substrates. The cells were found to express CYP27A mRNA and to convert the respective substrates into the same products as recombinantly expressed CYP27A, i.e. 25-hydroxyvitamin $\mathrm{D}_{3}$ and 27-oxygenated $\mathrm{C}_{27}$-sterols. The results of the present study describing the structure and expression of CYP27A in kidney suggest that this enzyme is involved in the renal metabolism of vitamin $\mathrm{D}_{3}$ and that the kidney plays a role in the metabolism of cholesterol and other $\mathrm{C}_{27}$-sterols.

Key words: bile acids, cholesterol, sterol 27-hydroxylase, vitamin D hydroxylases.

\section{INTRODUCTION}

Liver mitochondrial sterol 27-hydroxylase (CYP27A) is a multifunctional cytochrome P450 that is known to catalyse the 27oxygenation of $\mathrm{C}_{27}$-steroids in the formation of bile acids. A 27-hydroxylation initiates degradation of the $\mathrm{C}_{27}$-steroid side chain. The subsequent oxidation of the 27-hydroxysterol into the corresponding $\mathrm{C}_{27}$-acid can also be catalysed by CYP27A [1-5]. Another important reaction carried out by hepatic CYP27A is the 25-hydroxylation of vitamin $\mathrm{D}_{3}$ (cholecalciferol), which is the first step in the conversion of the inactive vitamin into the biologically active $1 \alpha, 25$-dihydroxyvitamin $\mathrm{D}_{3}$ [2,6-8]. In addition, experiments with purified and recombinantly expressed liver CYP27A have shown that the enzyme is also able to catalyse the $1 \alpha$-hydroxylation step $[9,10]$. Recent progress in the biochemistry of $1 \alpha, 25$-dihydroxyvitamin $D_{3}$ has disclosed its physiological importance as a hormone not only in the maintenance of calcium and phosphorus homoeostasis, but also in regulation of cellular differentiation [11-13].

It is well established that sterol 27-hydroxylase is obligatory for bile acid biosynthesis, which is considered to take place only in the liver $[1,2]$. However, the demonstration by Northern blot analysis that CYP27A mRNA is expressed in many tissues indicates a broader biological role for this enzyme [3]. Patients with the rare inherited lipid storage disease cerebrotendinous xanthomatosis have a deficient sterol 27-hydroxylase due to point mutations of the $C Y P 27 A$ gene [14-16]. Manifestations of this genetically determined CYP27A deficiency range from accelerated atherosclerosis, extensive osteoporosis and increased risk for bone fractures to progressive neurological impairment [14,17]. These findings indicate that CYP27A also has an important metabolic role in extrahepatic tissues.
Sterol 27-hydroxylase has been reported to produce oxysterols, such as 24, 25- and 27-hydroxycholesterol, which affect the regulation of several genes [18-22]. A mechanism for the elimination of cholesterol from macrophages and endothelial cells involving the 27-hydroxylation of cholesterol and subsequent oxidation into the $\mathrm{C}_{27}$-acid has been described [23]. It was proposed that this mechanism may also be utilized for elimination of cholesterol from other tissue cells. Although possible roles for CYP27A in various tissues have been suggested, there is no information available on the complete structure or expression of a functional enzyme from an extrahepatic CYP27A cDNA.

The 27-hydroxylation of cholesterol and the 25-hydroxylation of vitamin $\mathrm{D}_{3}$ in pig kidney have so far only been characterized by enzymic analysis of partially purified enzyme fractions and by immunological methods [24-26]. The availability of a cDNA for renal CYP27A should be a prerequisite for detailed studies on the biological role of this enzyme in the kidney. A cDNA encoding CYP27A in the pig has not previously been isolated or characterized. In the present paper we report the isolation, sequence determination and expression of a cDNA encoding pig kidney CYP27A that is active in the 25-hydroxylation of vitamin $\mathrm{D}_{3}$ and the 27-oxygenation of $\mathrm{C}_{27}$-sterols.

\section{EXPERIMENTAL}

\section{Materials}

25-Hydroxy[23,24(n)- $\left.{ }^{3} \mathrm{H}\right]$ vitamin $\mathrm{D}_{3}(100 \mathrm{Ci} / \mathrm{mmol}),\left[\alpha^{-32} \mathrm{P}\right] \mathrm{CTP}$ (3000 Ci/mmol), $\left[\alpha^{-35} \mathrm{~S}\right] \mathrm{ATP}(1000 \mathrm{Ci} / \mathrm{mmol})$, the Megaprime DNA labelling system and restriction endonucleases were purchased from Amersham. Unlabelled vitamin $\mathrm{D}_{3}$ was from Sigma, and 25-hydroxyvitamin $\mathrm{D}_{3}$ was obtained from Solvay (Duphar, The Netherlands). $1 \alpha$-Hydroxyvitamin $D_{3}$ was generously

Abbreviation used: RACE, rapid amplification of cDNA ends

1 To whom correspondence should be addressed (e-mail Kjell.Wikvall@farmbio.uu.se). 
Table 1 Oligonucleotide primers used in the present study

Restriction endonuclease recognition sites used for subcloning of PCR fragments are indicated in italics (5'-RACE anchor primer and 5'-RACE UAP, Sall; PK5'-end, Xbal).

\begin{tabular}{ll}
\hline Name & Sequence \\
\hline 5'-RACE anchor primer & 5'-CUACUACUACUAGGCCACGCGTCGACTAGTACGGGIIGGGIIGGGIIG-3' \\
5'-RACE UAP & 5'-CUACUACUACUAGGCCACGCGTCGACTAGTAC-3' \\
PK1 (GSP1) & 5'-CTCACGAGGACTGAGCTGTCGCTGGT-3' \\
PK2 (GSP2) & 5'-CATGAAGTCATCGACCACCTCATT-3' \\
PK5'-end & 5'-CGCTGCTCTAGAATGGCTGCGCTGGGCTGCGCGAGGCTGCGGTGGGCGCTGC-3' \\
\end{tabular}

donated by Leo (Copenhagen, Denmark). $5 \beta-\left[7 \beta-{ }^{3} \mathrm{H}\right]$ Cholestane$3 \alpha, 7 \alpha$-diol and $5 \beta$ - $\left[7 \beta-{ }^{3} \mathrm{H}\right]$ cholestane- $3 \alpha, 7 \alpha, 12 \alpha$-triol $(500 \mathrm{mCi} /$ $\mathrm{mmol}$ ) were synthesized as described previously [24]. Oligo(dT)cellulose, T3 and T7 primers and the pSVL expression vector were from Pharmacia. The Librarian " cDNA construction system was from Invitrogen. Gigapack II Gold packaging extracts, $\lambda$ ZAP II cloning kit and pBluescript II $\mathrm{KS}^{-}$and $\mathrm{SK}^{-}$were from Stratagene, and the Sequenase Version 2.0 DNA sequencing kit was from United States Biochemicals. The 5'-RACE (rapid amplification of cDNA ends) system and medium for cell cultures were obtained from Life Technologies. Nitrocellulose BA 85 disc membranes used in hybridization experiments were obtained from Schleicher \& Schuell, and T4 DNA ligase was from New England Biolabs. The adrenodoxin expression vector, $\mathrm{pBadX}$, was generously provided by Professor David Russell (Department of Molecular Genetics, University of Texas Southwestern Medical Center, Dallas, TX, U.S.A.). Wizard ${ }^{\star}$ DNA purification and reverse transcription systems were from Promega, and oligonucleotide primers were purchased from Scandinavian Gene Synthesis. Taq polymerase, deoxynucleotides and $10 \times$ buffer IV containing $15 \mathrm{mM} \mathrm{MgCl} \mathrm{m}_{2}$ used in PCR reactions were obtained from Advanced Biotechnologies. Human embryonic kidney 293 cells (ATCC CRL 1573) were obtained from American Type Culture Collection (Rockville, MD, U.S.A.). The remaining chemicals were of the highest quality available. Homology searches were performed using the NCBI database and the BLAST network service.

\section{RNA isolation}

Total RNA was isolated from $10 \mathrm{~g}$ of pig kidney or liver, and poly $(\mathrm{A})^{+}$RNA was prepared by oligo(dT)-cellulose chromatography according to standard procedures [27].

\section{Library construction and cDNA cloning}

Pig kidney cDNA was prepared from kidney poly(A) ${ }^{+}$RNA according to the manufacturer's instructions (Invitrogen), ligated into $\lambda$ ZAP II arms and packed to reveal the library. The pig kidney cDNA library was screened with a ${ }^{32} \mathrm{P}$-labelled rabbit liver CYP27A cDNA insert (bp 8-1641) [3] by standard methods [27]. Hybridization-positive clones were purified through several rounds of screening. Subcloning into pBluescript $\mathrm{SK}^{-}$was then performed.

\section{DNA sequence analysis}

Restriction fragments derived from the hybridization-positive clones were isolated and cloned into pBluescript $\mathrm{SK}^{-}$or pBluescript II $\mathrm{KS}^{-}$. The DNA sequence was generated directly from the double-stranded plasmids by the chain-termination method, and compression was resolved using 7-deaza-dGTP and
dITP. Electrophoresis was performed in $6 \%(\mathrm{w} / \mathrm{v})$ polyacrylamide gels containing $7 \mathrm{M}$ urea.

\section{Isolation of the $5^{\prime}$-end of the CYP27 cDNA}

Attempts to isolate the cDNA sequence encoding the mitochondrial leader sequence were performed using the $5^{\prime}$-RACE system according to the protocol supplied by the manufacturer (Life Technologies). The PK1 primer and pig kidney poly(A) ${ }^{+}$ RNA were used for first-strand synthesis, and primer PK2 as a nested primer together with the 5'-RACE anchor or UAP primer for PCR amplification (Table 1). Amplified fragments were subjected to digestion with $S a l \mathrm{I}$ and $K p n \mathrm{I}$ and cloned into the pBluscript $\mathrm{KS}^{-}$vector. PCR amplifications were carried out using an MJ Research minicycler. The reaction mixture contained first-strand cDNA obtained with the 5'-RACE system, $5 \mu 1$ of each primer $(10 \mu \mathrm{M})$ dissolved in water, $1 \mu \mathrm{l}$ of each of dATP, $\mathrm{dCTP}, \mathrm{dGTP}$ and dTTP $(200 \mu \mathrm{M})$, and $4.5 \mu \mathrm{l}$ of $10 \times$ reaction buffer containing $15 \mathrm{mM} \mathrm{MgCl}_{2}$ in a total volume of $45 \mu \mathrm{l}$. The reaction was overlaid with 2 drops of mineral oil in order to prevent evaporation and was kept at $95^{\circ} \mathrm{C}$ for $5 \mathrm{~min}$, followed by $80^{\circ} \mathrm{C}$ for $3 \mathrm{~min}$. During the latter period the reaction was initiated by the addition of 1 unit of Taq polymerase in $5 \mu \mathrm{l}$ of reaction buffer. The first two cycles were carried out at $94^{\circ} \mathrm{C}$ for $10 \mathrm{~min}, 50^{\circ} \mathrm{C}$ for $1 \mathrm{~min}$ and $72^{\circ} \mathrm{C}$ for $2 \mathrm{~min}$, followed by 38 cycles at $94{ }^{\circ} \mathrm{C}$ for $1 \mathrm{~min}, 50^{\circ} \mathrm{C}$ for $1 \mathrm{~min}$ and $72{ }^{\circ} \mathrm{C}$ for $2 \mathrm{~min}$. The last cycle was followed by a $10 \mathrm{~min}$ period at $72^{\circ} \mathrm{C}$, and then the temperature was kept constant at $4{ }^{\circ} \mathrm{C}$. The fragment containing the entire coding region for the mitochondrial signal sequence was amplified using the 5'-RACE fragment as template together with the PK5'-end and PK2 primers (Table 1), as described above. The amplified fragment (fragment 1; see Figure 2) was cloned into the pBluescript $\mathrm{KS}^{-}$vector after digestion with $X b a \mathrm{I}$ and $K p n \mathrm{I}$.

\section{Northern blot analysis}

Analysis of CYP27 transcripts was carried out following electrophoresis of poly $(\mathrm{A})^{+} \mathrm{RNA}$ on denaturing $1 \%$ agarose gels containing formaldehyde. Following transfer of the RNA to a nitrocellulose filter, hybridization was carried out at $42{ }^{\circ} \mathrm{C}$ for $16 \mathrm{~h}$ with a ${ }^{32} \mathrm{P}$-labelled $1746 \mathrm{bp}$ pig kidney cDNA fragment in hybridization buffer containing $50 \%$ formamide, $5 \times \mathrm{SSC}$ $(1 \times \mathrm{SSC}$ is $0.15 \mathrm{M} \mathrm{NaCl} / 0.015 \mathrm{M}$ sodium citrate), $1 \times \mathrm{PE}$ (50 mM Tris/ $\mathrm{HCl}, \mathrm{pH} 7.5,0.1 \%$ sodium pyrophosphate, $1 \%$ SDS, $0.2 \%$ polyvinylpyrrolidone, $0.2 \%$ Ficoll, $5 \mathrm{mM}$ EDTA and $0.2 \%$ BSA), $100 \mu \mathrm{g} / \mathrm{ml}$ salmon sperm DNA and $100 \mu \mathrm{g} / \mathrm{ml}$ tRNA. After hybridization the filter was washed in $2 \times \mathrm{SSC}$ containing $0.1 \%$ SDS at room temperature, followed by washing at $55{ }^{\circ} \mathrm{C}$ for $2 \mathrm{~h}$ in $0.1 \times \mathrm{SSC}$ containing $0.1 \% \mathrm{SDS}$, and then used to expose Fuji RX film in the presence of an intensifying 
screen for $12 \mathrm{~h}$ at $-70^{\circ} \mathrm{C}$. The filter was then stripped and probed with a $1.7 \mathrm{~kb}$ Bam $\mathrm{HI}-\mathrm{SalI}$ fragment of human $\beta$-actin cDNA. In Northern blot experiments with total RNA from human embryonic kidney 293 cells, a ${ }^{32} \mathrm{P}$-labelled human liver CYP27A cDNA fragment was used [5].

\section{Southern blot analysis}

Pig genomic DNA (Clontech) was digested with EcoRI, SacI, $B g l \mathrm{II}$ or $E c o \mathrm{RV}$, and $10 \mu \mathrm{g}$ of DNA from each digestion was electrophoresed in agarose, transferred to a nylon membrane, and probed with the ${ }^{32} \mathrm{P}$-labelled $1746 \mathrm{bp}$ pig kidney CYP27A cDNA $[3,6]$.

\section{Construction of pig kidney CYP27 expression vector}

Fragment 1 containing the nucleotide sequence encoding the entire mitochondrial signal sequence in pBluescript $\mathrm{KS}^{-}$and clone 1 in pBluescript $\mathrm{SK}^{-}$(see Figure 2) were subjected to digestion with $X b a \mathrm{I} / K p n \mathrm{I}$ and $K p n \mathrm{I} / B a m \mathrm{HI}$ respectively. A 472 bp XbaI/KpnI fragment and a 1398 bp KpnI/BamHI fragment were isolated and ligated into the pSVL vector digested with $X b a \mathrm{I}$ and $B a m \mathrm{HI}$ to generate the expression plasmid pSVLPK27.

\section{Transfection in COS-M6 cells}

COS-M6 cells were cultured in Dulbecco's modified Eagle's medium supplemented with $10 \%$ (v/v) fetal calf serum and antibiotics. The cells were transfected with the pSVL expression vector containing pig kidney CYP27 cDNA [9]. Substrates, dissolved in $10 \mu \mathrm{l}$ of DMSO $(0.3 \%$ final concentration $)$, were added to $5 \times 10^{5}$ cells in each experiment and incubated for $48 \mathrm{~h}$ prior to analysis of products in the cell medium. The substrates were: $10 \mu \mathrm{g}$ of ${ }^{3} \mathrm{H}$-labelled $5 \beta$-cholestane- $3 \alpha, 7 \alpha$-diol, $10 \mu \mathrm{g}$ of ${ }^{3} \mathrm{H}$-labelled $5 \beta$-cholestane- $3 \alpha, 7 \alpha, 12 \alpha$-triol, $10 \mu \mathrm{g}$ of vitamin $\mathrm{D}_{3}$ and $10 \mu \mathrm{g}$ of $1 \alpha$-hydroxyvitamin $\mathrm{D}_{3}$. Incubations with $5 \beta$ cholestane- $3 \alpha, 7 \alpha$-diol and $5 \beta$-cholestane- $3 \alpha, 7 \alpha, 12 \alpha$-triol were extracted with acidified ether [28], and those containing vitamin $\mathrm{D}_{3}$ and $1 \alpha$-hydroxyvitamin $\mathrm{D}_{3}$ were extracted with trichloroethane/methanol $(2: 1, \mathrm{v} / \mathrm{v})$, as described [24,25]. Incubations with $5 \beta$-cholestane- $3 \alpha, 7 \alpha$-diol and $5 \beta$-cholestane- $3 \alpha, 7 \alpha, 12 \alpha$-triol were analysed by TLC and radioactivity scanning [28]. Incubations with vitamin $D_{3}$ and $1 \alpha$-hydroxyvitamin $D_{3}$ were analysed by straight-phase and reverse-phase HPLC, as described [24,25].

\section{Cultures of human embryonic kidney cells}

Human embryonic kidney cells (293 cells) were seeded at $7.5 \times 10^{5}$ cells per $60 \mathrm{~mm}$ tissue culture dish in Dulbecco's modified Eagle's medium supplemented with $10 \%$ (v/v) fetal calf serum and antibiotics. Enzymic activities in the cells were examined by addition of the respective substrates [vitamin $D_{3}(10 \mu \mathrm{g}), 1 \alpha$ hydroxyvitamin $\mathrm{D}_{3}(10 \mu \mathrm{g})$ or ${ }^{3} \mathrm{H}$-labelled $5 \beta$-cholestane$3 \alpha, 7 \alpha$-diol $(20 \mu \mathrm{g})$, dissolved in $10 \mu \mathrm{l}$ of DMSO $(0.3 \%$ final concentration)] to the medium and incubation for 24 or $72 \mathrm{~h}$. Following incubation with substrate, the medium was collected and extracted with trichloroethane/methanol $(2: 1, \mathrm{v} / \mathrm{v})$ or acidified ether, and the organic phase was analysed for hydroxylated metabolites.

\section{Other methods}

Adrenodoxin and adrenodoxin reductase were prepared and protein determination was performed as described previously [28].

\section{RESULTS}

\section{cDNA cloning}

Screening of $5 \times 10^{5}$ plaques of a pig kidney $\lambda$ ZAPII cDNA library with a ${ }^{32} \mathrm{P}$-labelled rabbit liver CYP27A cDNA insert (bp 8-1641) [3] resulted in five positive clones, which were purified through several rounds of screening. In vivo excision to form the $\mathrm{pBluescript} \mathrm{SK}^{-}$plasmid revealed the plasmid to contain cDNA inserts varying in size between $\approx 1000 \mathrm{bp}$ and $1746 \mathrm{bp}$. Attempts to isolate the 5'-end of the cDNA were performed using the 5'-RACE system. Pig kidney poly(A) ${ }^{+}$RNA and the PK1 primer were used for first-strand synthesis. Primer PK2 was then used as a nested primer together with the 5'-RACE anchor or UAP primer (see Table 1) for PCR amplification. The longest fragment isolated ( $5^{\prime}$-RACE; see Figure 2 ) was, however, missing the first $22 \mathrm{bp}$ of the mitochondrial leader sequence. The $5^{\prime}$-end of the pig kidney CYP27 cDNA containing the entire coding region of the mitochondrial leader sequence was amplified by

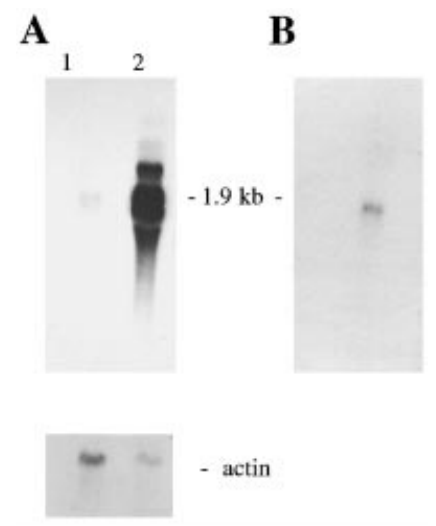

Figure 1 Northern blot analysis of RNA isolated from pig kidney and liver (A) and human embryonic kidney cells (B)

(A) Poly $\left(\mathrm{A}^{+}\right)$RNA was isolated from kidney and liver by the guanidine- $\mathrm{HCl}$ procedure followed by oligo(dT) chromatography. Portions of $10 \mu \mathrm{g}$ of kidney mRNA (lane 1 ) and $5 \mu \mathrm{g}$ of liver mRNA (lane 2) were electrophoresed on a 1\% (w/v) agarose gel, blotted and hybridized with pig kidney CYP27A cDNA by standard methods. After autoradiography for $12 \mathrm{~h}$ the filter was stripped and hybridized with human $\beta$-actin cDNA. (B) A portion of $30 \mu \mathrm{g}$ of total RNA isolated from human embryonic kidney 293 cells was subjected to the same procedure as in $(\mathbf{A})$, with the exception that a human CYP27A cDNA [5] was used as the labelled probe.

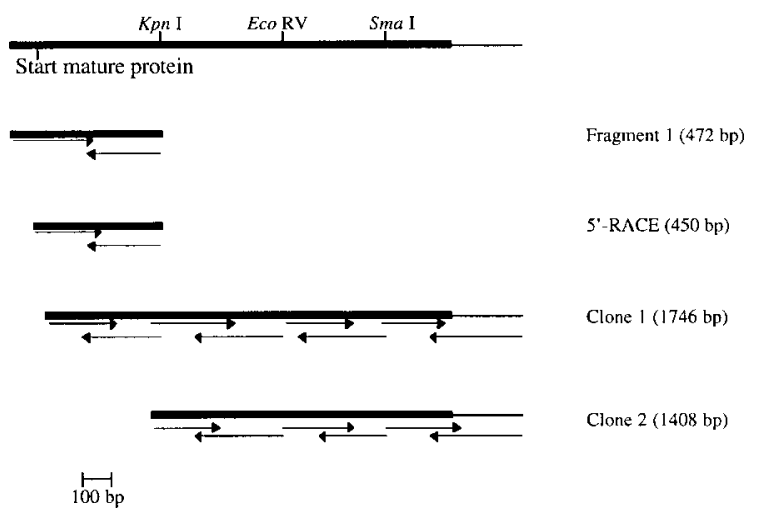

Figure 2 Restriction map and sequencing strategy for the pig kidney CYP27 CDNA and fragments

Arrows indicate the direction and extent of sequencing 


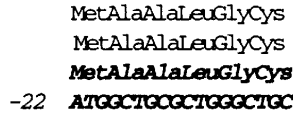

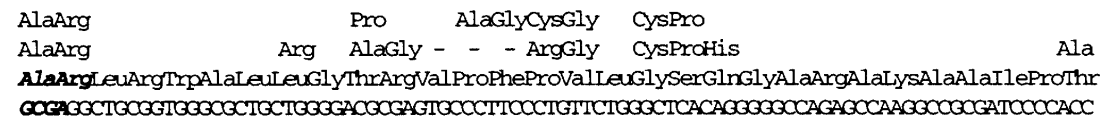

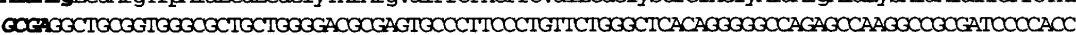

Aspgluala Gln Ala Asparg Arg Ser Glu ProArgLeu

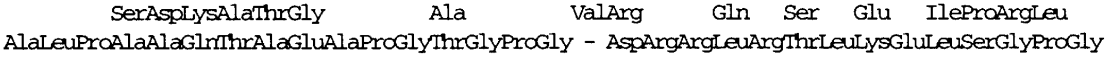

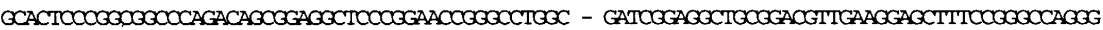

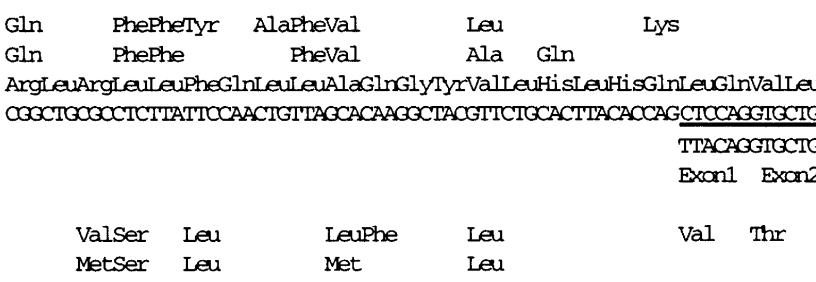

MetTrpIleAsrTyrIleGlyProGinIleHisValAsnValAlaSerAlaProLeuLeuGluGlnValMetAngGlnGluGlyLysTyr ATGTGGATAAACTATATAGGGCCTCAGATCCATGTGAACGTGGCCAGTGCCCCACTCCTGGAGCAAGTGATGCGCCAAGAGGGCAAGTAC

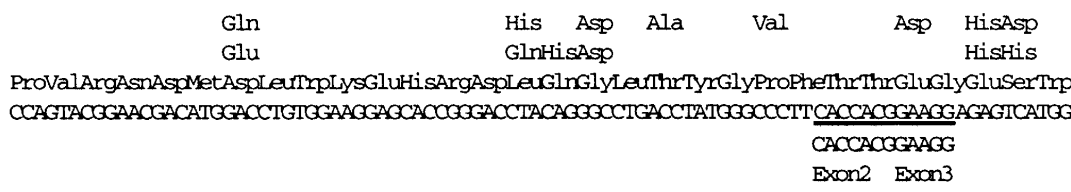

eUASMLYSAlaLYYSTYRGIYPro

GCTGACAAGOCCAAGTATGGTCCA

Exon2 Exan3

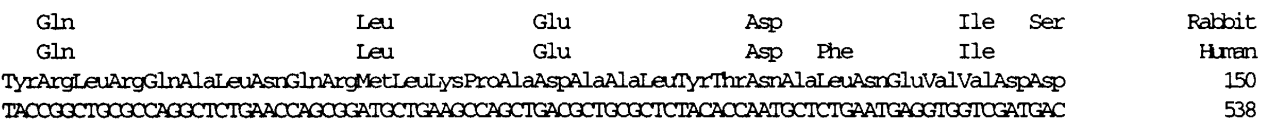

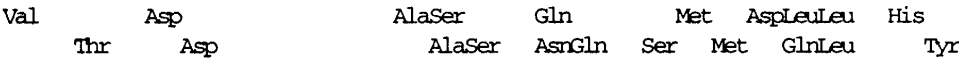

PheMetValArgLeuAsnGInLeuArgAlaGluSerThrLeuGlyAspHisValProAspIleAlaHisGlnPheTyrPhePheAlaLeu TTCATGGTGOCACTGAACCAGCTICGGOCAGAAAOCACCTTGOOOGACCACGIGCCCGACATAGCTCACCAATTCTACTTCTTOBOCT" IG

Arg Ala Lys GluAsn Ile Rabbit

Arg Gln Glu ValThr Ile Human

GluAlaIleCySTyrIleLeuPheGluLysHisIleGlyCysLeuGluArgSerIleProGlnAspThrLysAlaPheValArgSerVal GAAGCTATTT GCTACATCCTGTTTGAGAAACACATTGGCTGCCTGGAGCGCTCCATCCCCCAGGACACCAAAGCCTTLGTCAGATCTGTC GAAGCTATTT

an3 Exant

Rabbit

Human

Rabbit

Human

Rabbit

Humen

30

Rabbit

Human

60
268

Rabbit

Himan

358

Rabbit Human

120

448

Rabbit

150

538

Rabbit Human

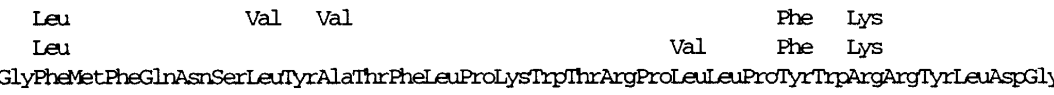

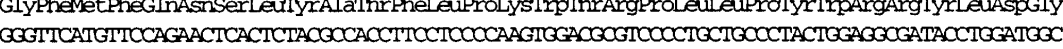

Rabbit

Human

240

808

ASP

Asn

Gln Valval

SerAla SerAspgly Aspimet

Ala AspGly

TrpAsmihrIlePheSerPheGlyLysLysLeuIl eAspGInLysLeuGluGluIleGluAlaGInLeuGInAlaGlyGlyProGluGlu

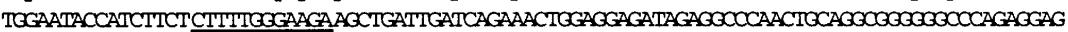
CTTTTGOGAACA

Exan4 Exan5

Valglnval

Ser

Phe

Ala

Leu

Leu

ProArgIleSerGlyTyrLeuHisLeuLeuLeuThrSerGlyGInLeuSerProArgGluAlaGluGlySerLeuProGluLeuLeuMet CCOCOCATATCTGGTTAOCTGCACTTOCTOCTTACCAGCOGACAOCTCAGTOCTOGIGAGOCTGAGGOCAGCTTGOCOGAGCTGCTCATG
Rabbit Human 270 898

Rabbit Himan 300 988

Figure 3 For legend see facing page. 


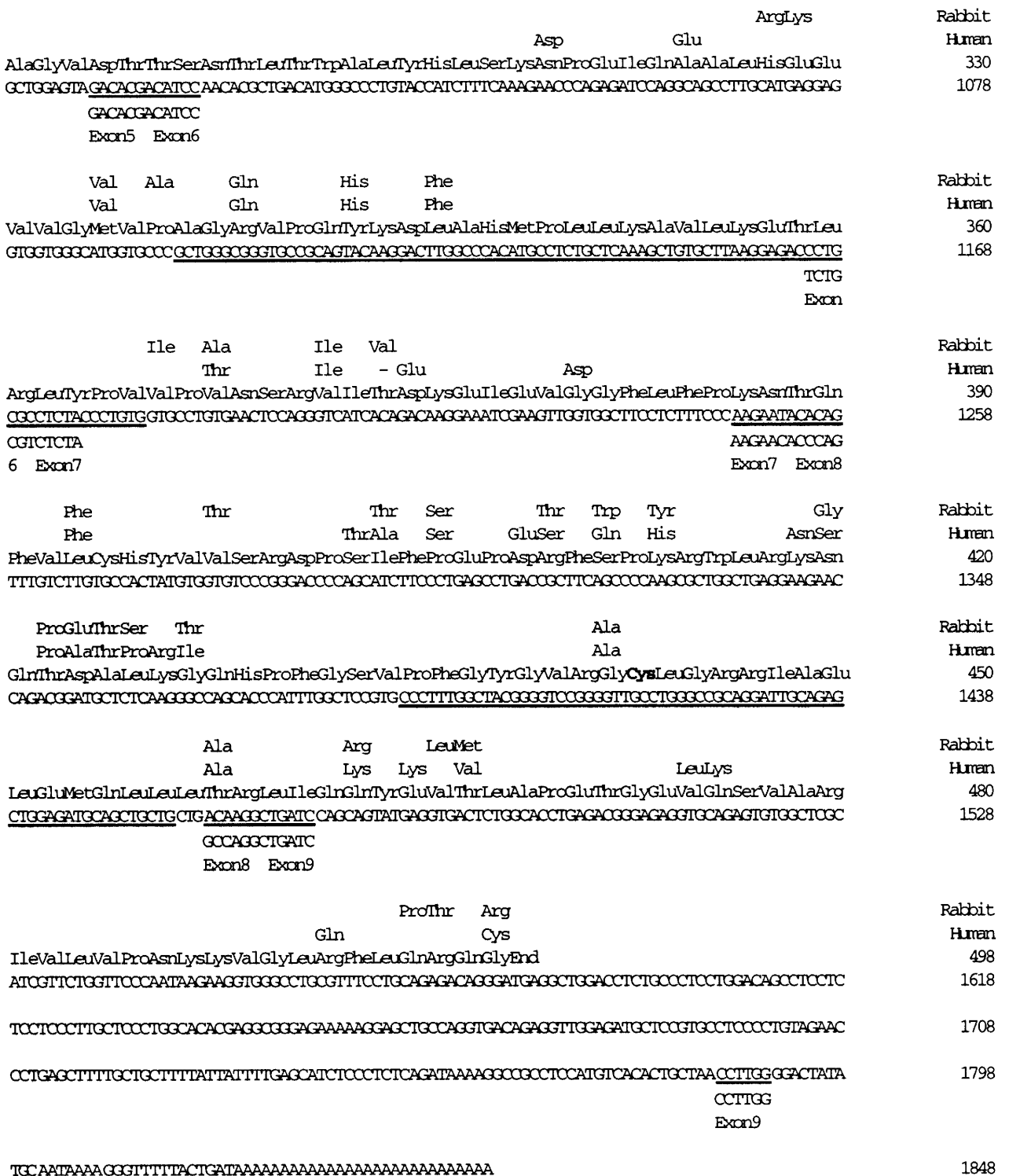

\section{Figure 3 Sequence of the pig kidney CYP27 CDNA and protein, and comparison with the human and rabbit liver enzymes}

Nucleotides and amino acids are numbered on the right. A polyadenylation signal in the $3^{\prime}$-untranslated region of the CDNA is indicated by an underline, as are the possible ferredoxin-binding region and the conserved haem binding region, in which the cysteine predicted to be the ligand for the haem group is indicated in bold (residue 443). Amino acids of the human and rabbit liver proteins that differ from those of the pig kidney enzyme are shown above the pig enzyme sequence. Indicated below the nucleotide sequence are the exon-intron junctions identified from the human gene [16] and their nucleotide sequence. The first amino acid in the mature protein is indicated by an arrow. The amino acids and nucleotides corresponding to the mitochondrial leader sequences not present in the cloned CDNA are indicated in bold.

PCR using the primers PK5'-end and PK2 (see Table 1) and the 5'-RACE fragment as template. The PK5' primer sequence contained a $X b a$ I site and nucleotides -22 to 18 (see Figure 3). The PK2 primer hybridizes to the sequence corresponding to nucleotides 521-544 in Figure 3.

\section{Northern blot analysis}

The size of the mRNA was determined by Northern blot hybridization using the $1746 \mathrm{bp}$ cDNA as probe. As shown in Figure 1, the probe hybridized to mRNA of approx. $1.8 \mathrm{~kb}$ in size. The pig kidney cDNA probe hybridized to mRNA with the same molecular size in pig liver. The intensity of the band in liver was significantly greater than that in kidney (Figure 1A).
Although difficult to resolve, two closely spaced hybridizing mRNAs appeared to be present in both kidney and liver. Andersson et al. [3] previously reported the same pattern for rabbit CYP27 in adrenal gland, lung and kidney, but not in liver.

\section{DNA sequence analysis}

The largest clones (clones 1 and 2; Figure 2), the 5'-RACE clone and fragment 1 were subjected to restriction mapping and nucleotide sequencing. Figure 2 shows the restriction map and sequencing strategy for the pig kidney CYP27 cDNA and fragments. Fragment 1 and a 1398 bp KpnI-BamHI fragment of clone 1 were joined to produce a DNA fragment containing the entire amino acid sequence of the pig kidney CYP27 protein. 


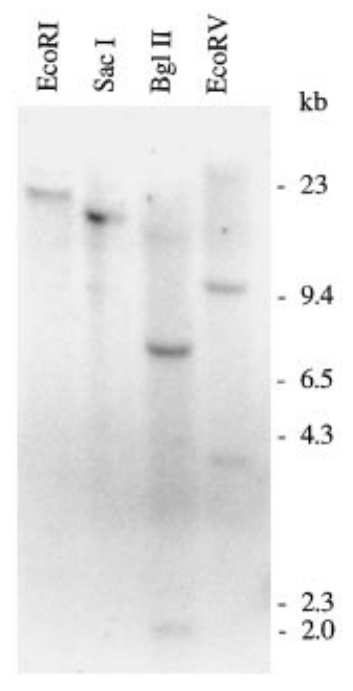

\section{Figure 4 Southern blot analysis}

Pig genomic DNA was digested with EcoRI, Sacl, Bg/ll or EcoRV, and $10 \mu \mathrm{g}$ portions of digested DNA were subjected to Southern blot analysis, as described in the Experimental section, using pig kidney CYP27A cDNA as probe.

Figure 3 shows the nucleotide and deduced amino acid sequence of the pig kidney CYP27 cDNA, as determined by analysis of the cDNA inserts in the clones and the 5'-RACE fragment. The first 36 amino acids (residues -36 to -1 ) of the cDNA sequence have many hallmarks of a mitochondrial signal sequence. The mature pig kidney CYP27 contains 498 amino acids and has an overall hydrophobic nature. The $M_{\mathrm{r}}$ of the mature protein was calculated as 56607 , which is slightly greater than that estimated by SDS/PAGE (53000). The haem-liganded cysteine that is conserved in all cytochrome $\mathrm{P} 450$ proteins occurs at residue 443. A short 3'-untranslated region of 265 bp was present in both clones and contains a consensus AATAAA sequence for polyadenylation (Figure 3).

The pig kidney CYP27 cDNA shares high similarity with reported sequences of liver CYP27A enzymes. Alignment indicated $79 \%$ sequence similarity with that from human [5], 78\% similarity with that from rabbit [3] and $71 \%$ similarity with that from rat [6,7]. The amino acid sequence displays $83 \%, 81 \%$ and $77 \%$ similarity with human, rabbit and rat CYP27A respectively [3,5-7]. The cloned human $C Y P 27 A$ gene contains nine exons and eight introns [16]. The junctions between the exons and introns in the human gene have all been identified in the kidney cDNA, as well as the conserved regions around the haemliganded cysteine (residues 435-456) and residues 337-365, which may form part of the ferredoxin binding domain [29].

\section{Genomic Southern blot analysis}

It has been reported previously that CYP27A appears to be encoded by a single gene in rabbit [3] and rat [6]. To estimate the number of $C Y P 27 A$ genes in the pig genome, we carried out Southern blotting experiments. Pig genomic DNA was digested separately with four restriction enzymes and electrophoresed, transferred to nylon membranes and hydrbridized with the probe employed in Northern blotting experiments, as described in the Experimental section. As demonstrated in Figure 4, a small number of hybridizing bands was visualized in each lane of the gel. The restriction enzymes EcoRI and SacI, which do not cut
Table 2 Hydroxylase activities in COS-M6 cells transfected with pig kidney CYP27A CDNA

Transfection experiments were performed as described in the Experimental section. As negative controls, COS-M6 cells were transfected with the pSVL vector containing no insert. Unlabelled vitamin $\mathrm{D}_{3}$ or $1 \alpha$-hydroxyvitamin $\mathrm{D}_{3}$, or ${ }^{3} \mathrm{H}$-labelled $5 \beta$-cholestane- $3 \alpha, 7 \alpha$-diol or $5 \beta$ cholestane- $3 \alpha, 7 \alpha, 12 \alpha$-triol ( $8 \mu \mathrm{M}$ of each substrate), was added to the culture medium containing approx. $5 \times 10^{5}$ cells in each experiment. On day 2 after substrate addition, the medium was removed for assay of product formation and the cells were harvested for protein determination. Product formation is expressed as $\mathrm{pmol} / \mathrm{mg}$ of protein. The results from four experiments are given as means \pm S.D. The amount of substrate converted into product during the incubation was approx. $0.5 \%$ for vitamin $D_{3}, 1.5 \%$ for $1 \alpha$-hydroxyvitamin $D_{3}, 9 \%$ for $5 \beta$ cholestane- $3 \alpha, 7 \alpha$-diol and $90 \%$ for $5 \beta$-cholestane- $3 \alpha, 7 \alpha, 12 \alpha$-triol.

\begin{tabular}{lcc}
\hline & Product formation (pmol/mg of protein) \\
\cline { 2 - 3 } Reaction measured & $\mathrm{pSVL}$ & $\mathrm{pSVL-PK27}$ \\
\hline Vitamin $\mathrm{D}_{3}$ 25-hydroxylation & $<2$ & $32 \pm 8$ \\
$1 \alpha$-Hydroxyvitamin $\mathrm{D}_{3}$ 25-hydroxylation & $<2$ & $105 \pm 11$ \\
$5 \beta$-Cholestane-3 $\alpha, 7 \alpha$-diol 27-hydroxylation & $<10$ & $700 \pm 81$ \\
$5 \beta$-Cholestane-3 $\alpha, 7 \alpha, 12 \alpha$-triol & & \\
27 -Hydroxylation & $<10$ & $5705 \pm 419$ \\
Oxidation to acid & $<10$ & $1925 \pm 888$ \\
\end{tabular}

Table 3 Endogenous hydroxylase activities in human embryonic kidney cells

Human embryonic kidney 293 cells were cultured and enzyme activities were assayed as described in the Experimental section. The amount of substrate added was $8 \mu \mathrm{M}$ (vitamin $\mathrm{D}_{3}$ and $1 \alpha$-hydroxyvitamin $\left.\mathrm{D}_{3}\right)$ or $16 \mu \mathrm{M}(5 \beta$-cholestane- $3 \alpha, 7 \alpha$-diol). Product formation is expressed as $\mathrm{pmol} / \mathrm{mg}$ of protein. The results from three experiments are given as means \pm S.D. The amount of substrate converted into product during the incubation was approx. $2 \%$ for vitamin $\mathrm{D}_{3}, 3 \%\left(24 \mathrm{~h}\right.$ ) and $10 \%(72 \mathrm{~h})$ for $1 \alpha$-hydroxyvitamin $\mathrm{D}_{3}$, and $16 \%(24 \mathrm{~h})$ and $70 \%$ (72 h) for $5 \beta$-cholestane- $3 \alpha, 7 \alpha$-diol. ND, not determined.

\begin{tabular}{lcc}
\hline & Product formation (pmol/mg of protein) \\
\cline { 2 - 3 } Reaction measured & $24 \mathrm{~h}$ & $72 \mathrm{~h}$ \\
\hline Vitamin $\mathrm{D}_{3} 25$-hydroxylation & $220 \pm 39$ & $\mathrm{ND}$ \\
$1 \alpha$-Hydroxyvitamin $\mathrm{D}_{3} 25$-hydroxylation & $350 \pm 130$ & $1000 \pm 325$ \\
$5 \beta$-Cholestane-3 $\alpha, 7 \alpha$-diol 27-hydroxylation* & $2000 \pm 644$ & $8600 \pm 850$ \\
* Analysis of $72 \mathrm{~h}$ incubations by TLC also revealed another polar product with an $R_{F}$ value \\
corresponding to that of $3 \alpha, 7 \alpha$-dihydroxy-5 $\beta$-cholestanoic acid.
\end{tabular}

the cDNA, yielded only single bands. BglII and EcoRV, which do cut the cDNA, yielded two to three bands. These results suggest the presence of a single gene for CYP27A in the pig.

\section{PCR experiments with RNA from pig kidney and liver}

Since the structure of pig liver CYP27A cDNA is not known, we carried out PCR experiments with RNA from kidney and liver in order to compare sequences of CYP27A in the two tissues. Firststrand cDNA was synthesized using the random primer method (Reverse Transcription System; Promega). Primers hybridizing to nucleotides 614-633 (forward primer) and 1427-1447 (reverse primer) in the pig kidney CYP27A cDNA (cf. Figure 3) were then used in the PCR experiments. A DNA fragment of the same size, $833 \mathrm{bp}$, was amplified from the cDNA of both liver and kidney. The nucleotide sequence of the liver and kidney fragments was the same. Taken together, the results from the Southern blotting and PCR experiments strongly indicate that CYP27A in kidney and liver is encoded by a single gene in the pig. 


\section{Expression of the pig kidney CYP27A cDNA in COS-M6 cells}

To confirm that the sequence shown in Figure 3 encodes a functional enzyme, we expressed the cDNA in simian COS-M6 cells. A DNA fragment corresponding to nucleotides 22-1848 (see Figure 2) was ligated into the eukaryotic expression vector pSVL to generate the pSVL-PK27 vector. The expression vector was transfected, together with the pBadX plasmid encoding bovine adrenodoxin, into COS cells by the DEAE-dextran method [9]. As control, COS cells transfected with vector containing no insert were used. Table 2 shows that COS cells transfected with pSVL-PK27 catalysed the 25-hydroxylation of vitamin $\mathrm{D}_{3}$ and $1 \alpha$-hydroxyvitamin $\mathrm{D}_{3}$ and the 27 -hydroxylation of $5 \beta$-cholestane- $3 \alpha, 7 \alpha$-diol and $5 \beta$-cholestane- $3 \alpha, 7 \alpha, 12 \alpha$-triol, whereas the mock-transfected cells did not. The transfected cells also catalysed the further oxidation of $5 \beta$-cholestane$3 \alpha, 7 \alpha, 12 \alpha, 27$-tetrol into its corresponding $\mathrm{C}_{27}$-acid, $3 \alpha, 7 \alpha, 12 \alpha$ trihydroxy- $5 \beta$-cholestanoic acid.

\section{7-0xygenation of $C_{27}$-sterols and 25-hydroxylation of vitamin $D_{3}$ by human embryonic kidney cells}

In order to study the catalytic activities towards vitamin $\mathrm{D}_{3}$ and $\mathrm{C}_{27}$-sterols in a kidney cell line, we examined the 27-hydroxylase and 25-hydroxylase activities in human embryonic kidney cells (293 cells). The cultured cells converted vitamin $\mathrm{D}_{3}, 1 \alpha$-hydroxyvitamin $\mathrm{D}_{3}$ and $5 \beta$-cholestane- $3 \alpha, 7 \alpha$-diol into the same products as the recombinantly expressed kidney CYP27A, i.e. 25-hydroxyvitamin $\mathrm{D}_{3}, 1 \alpha, 25$-dihydroxyvitamin $\mathrm{D}_{3}$ and 27-oxygenated $\mathrm{C}_{27^{-}}$ sterol respectively (Table 3 ).

Northern blot experiments showed that the cells expressed CYP27A mRNA (Figure 1B).

\section{DISCUSSION}

The results of the present study, describing the molecular cloning, structure and functional expression of pig kidney CYP27A, imply that CYP27A has a biological role in kidney in the metabolism of vitamin $\mathrm{D}_{3}$ and $\mathrm{C}_{27}$-sterols.

\section{Renal metabolism of vitamin $\mathrm{D}_{3}$}

The recombinantly expressed kidney CYP27A catalysed the 25hydroxylation of vitamin $\mathrm{D}_{3}$, suggesting that the enzyme is involved in the formation of 25-hydroxyvitamin $\mathrm{D}_{3}$ in kidney. Although the liver is regarded as the most significant source of 25-hydroxyvitamin $\mathrm{D}_{3}$, several previous reports indicate that the liver is not the sole site for this 25-hydroxylation and that substantial activity can be shown to occur in other tissues, such as kidney [25,30-34]. Measurement of the concentrations of vitamin $D_{3}$ in various tissues has shown that vitamin $D_{3}$ is present in kidney in almost the same concentration as that found in liver [35]. The enzyme(s) responsible for the formation of 25hydroxyvitamin $\mathrm{D}_{3}$ in kidney has, however, not been character5ized. Mitochondrial CYP27A is known to be a vitamin $\mathrm{D}_{3} 25-$ hydroxylase in mammalian liver [2]. The present study, demonstrating the presence in kidney of CYP27A that has the capacity to convert vitamin $\mathrm{D}_{3}$ into 25 -hydroxyvitamin $\mathrm{D}_{3}$, supports a role for the kidney in the production of 25-hydroxyvitamin $\mathrm{D}_{3}$. The finding that human embryonic kidney cells express CYP27A mRNA and endogenous activity resulting in the formation of 25-hydroxyvitamin $\mathrm{D}_{3}$ lends further support to the contention that this metabolite is formed in kidney. Since kidney mitochondria contain both the 25-hydroxylating CYP27A and $1 \alpha$-hydroxylases [36-40] that convert 25 -hydroxyvitamin $\mathrm{D}_{3}$ into $1 \alpha, 25$-dihydroxyvitamin $\mathrm{D}_{3}$, the kidney would then be capable of the complete conversion of vitamin $\mathrm{D}_{3}$ into its hormonal form.

The role of hepatic CYP27A as a physiological vitamin $\mathrm{D}_{3} 25$ hydroxylase has been discussed [14,17,41,42]. Berginer et al. [17] found that extensive osteoporosis and increased risk of bone fractures occurred in some patients with cerebrotendinous xanthomatosis, caused by an anomaly of the $C Y P 27 A$ gene. The serum levels of some vitamin $\mathrm{D}_{3}$ metabolites, such as 25 -hydroxyvitamin $\mathrm{D}_{3}$ and 24,25-dihydroxyvitamin $\mathrm{D}_{3}$, were lower than normal in these patients [17]. Okuda et al. [42] have suggested that osteoporosis in these patients may be explained by low or null activity of the mitochondrial vitamin $\mathrm{D}_{3} 25$-hydroxylase, owing to the abnormal enzyme formed from the defective CYP27A gene. Other authors have questioned the role of CYP27A as a vitamin $\mathrm{D}_{3}$ 25-hydroxylase because of the finding that patients with cerebrotendinous xanthomatosis, lacking the CYP27A enzyme, and mice with a disrupted $C Y P 27 A$ gene do not have markedly reduced circulating 25-hydroxyvitamin $\mathrm{D}_{3}$ levels $[14,41]$. Although these findings argue against an important role for CYP27A in vitamin $\mathrm{D}_{3}$ metabolism, these data do not rule out the possible function of CYP27A as a 25-hydroxylase. The lack of effect on the levels of circulating vitamin $\mathrm{D}_{3}$ metabolites may, for example, be due to a compensatory increased activity of the microsomal vitamin $\mathrm{D}_{3}$ 25-hydroxylase [43] under these pathological and unphysiological conditions. The results of a recent study on vitamin $D_{3}$ hydroxylation in piglets suffering from rickets suggest that CYP27A is important for 25-hydroxyvitamin $\mathrm{D}_{3}$ production, at least in the pig [44].

The regulated $1 \alpha$-hydroxylation step is apparently catalysed by several cytochrome P450 enzymes in the kidney [36-40]. Studies with purified and recombinantly expressed liver CYP27A have shown that it catalyses $1 \alpha$-hydroxylation $[9,10]$, and experiments with partially purified pig kidney CYP27A have indicated that this enzyme plays a role as a renal mitochondrial $1 \alpha$ hydroxylase [45]. In the present study, the rate of $1 \alpha$-hydroxylation catalysed by the recombinantly expressed pig kidney CYP27A was below the limit of detection with the methods used. However, considering the similarities between kidney CYP27A and liver CYP27A in structure and other catalytic properties examined, it appears possible that the kidney CYP27A has the capacity to catalyse $1 \alpha$-hydroxylation.

\section{Renal metabolism of $\mathbf{C}_{27}$-sterols}

The recombinantly expressed kidney CYP27A enzyme also carried out the 27-hydroxylation of $\mathrm{C}_{27}$-sterols and the further oxidation into $\mathrm{C}_{27}$-acids. Cultured human embryonic kidney cells were found to express CYP27A mRNA and endogenous enzyme activity resulting in the formation of the same metabolites as those produced by the recombinantly expressed renal CYP27A. These findings, together with previous work describing partially purified 27-hydroxylase from kidney $[24,26]$, indicate that the kidney may play a hitherto unrecognized role in the metabolism of $\mathrm{C}_{27}$-sterols.

A possible physiological role for CYP27A in sterol metabolism in the kidney could be the formation of oxysterols, such as 27hydroxycholesterol, which appears to regulate cholesterol homoeostasis in several ways $[18,19,23,46,47]$. Liver mitochondrial CYP27A is known to carry out the 27-oxygenation of cholesterol and other $\mathrm{C}_{27}$-sterols, such as $5 \beta$-cholestane$3 \alpha, 7 \alpha, 12 \alpha$-triol. The rate of 27 -oxygenation is about 50 times lower with cholesterol than with $5 \beta$-cholestane- $3 \alpha, 7 \alpha, 12 \alpha$-triol $[10,28]$. The recombinantly expressed kidney CYP27A used in the present study catalysed the 27-oxygenation of $5 \beta$-cholestane- $3 \alpha$, $7 \alpha, 12 \alpha$-triol into $5 \beta$-cholestane- $3 \alpha, 7 \alpha, 12 \alpha, 27$-tetrol and $3 \alpha, 7 \alpha$, 
$12 \alpha$-trihydroxy-5 $\beta$-cholestanoic acid. Although the rate of 27 hydroxylation of cholesterol was below the limit of detection, it seems likely that CYP27A in kidney is capable of the 27oxygenation of cholesterol, and may be involved in the elimination of cholesterol [23].

The formation of bile acids is considered to take place only in the liver. It is surprising that, in spite of this contention, several enzymes involved in the biosynthesis and metabolism of bile acids are expressed in kidney. In a study on oxysterol $7 \alpha$ hydroxylase, Schwartz et al. [48] found that 25-hydroxycholesterol was $7 \alpha$-hydroxylated by human embryonic kidney cells. Work in our laboratory has shown that 27-hydroxycholesterol can also be $7 \alpha$-hydroxylated by this cell line (M. Norlin and K. Wikvall, unpublished work). Pedersen et al. [49] reported the molecular cloning of a $3 \alpha, 7 \alpha, 12 \alpha$-trihydroxy-5 $\beta$-cholestanoylCoA oxidase from rabbit liver peroxisomes. This enzyme catalyses the further oxidative cleavage of the steroid side chain after the formation of the $\mathrm{C}_{27}$-acid. The enzyme was also found to be expressed in kidney. The authors discussed the possibility that small amounts of cholesterol hydroxylated in the 27-position in other organs may eventually be further oxidized and chainshortened in the kidney. The results of the present udy show that CYP27A in kidney can produce the substrate for $3 \alpha, 7 \alpha, 12 \alpha-$ trihydroxy- $5 \beta$-cholestanoyl-CoA oxidase locally. Bile acid-CoA synthetase and bile acid-CoA:amino acid $N$-acyltransferase are two enzymes that catalyse the conjugation of bile acids with either taurine or glycine in the liver. Kwakye et al. [50,51] demonstrated the presence of these enzyme activities in rat kidney. The authors suggested that the kidney has the potential for bile acid metabolism, and may have a role in bile acid physiology. Taken together, these findings indicate a role for the kidneys in cholesterol metabolism. Since enzymes catalysing the 27-oxygenation, $7 \alpha$-hydroxylation and side-chain oxidation of cholesterol and cholesterol metabolites are expressed in kidney, the results in fact show that the kidney has the capacity for the formation and conjugation of bile acids.

In conclusion, the results of the characterization of pig kidney CYP27A described in the present study strongly indicate that CYP27A is involved in the renal metabolism of vitamin $\mathrm{D}_{3}$, and that the kidney plays a role in the metabolism of cholesterol and other $\mathrm{C}_{27}$-sterols.

The skilful technical assistance of Britt-Marie Johansson is gratefully acknowledged. This work was supported by the Swedish Medical Research Council (project 03X218).

\section{REFERENCES}

1 Björkhem, I. (1992) J. Lipid Res. 33, 455-471

2 Okuda, K. I. (1994) J. Lipid Res. 35, 361-372

3 Andersson, S., Davis, D. L., Dahlbäck, H., Jörnvall, H. and Russell, D. W. (1989) J. Biol. Chem. 264, 8222-8229

4 Dahlbäck, H. and Holmberg, I. (1990) Biochem. Biophys. Res. Commun. 167 391-395

5 Cali, J. J. and Russell, D. W. (1991) J. Biol. Chem. 266, 7774-7778

6 Su, P., Renner, H., Shayiq, R. M., Yamamoto, R., Zheng, Y.-M., Addya, S., Strauss, III, J. F. and Avadhani, N. G. (1990) DNA Cell Biol. 9, 657-665

7 Usui, E. and Okuda, K. (1990) FEBS Lett. 262, 135-138

8 Guo, Y.-D., Strugnell, S., Back, D. W. and Jones, G. (1993) Proc. Natl. Acad. Sci. U.S.A. 90, 8668-8672

9 Axén, E., Postlind, H., Sjöberg, H. and Wikvall, K. (1994) Proc. Natl. Acad. Sci. U.S.A. 91, 10014-10018

10 Pikuleva, I. A., Björkhem, I. and Waterman, M. R. (1997) Arch. Biochem. Biophys. 343, 123-130
11 Holick, M. F. (1994) Am. J. Clin. Nutr. 60, 619-630

12 Bouillon, R., Okamura, W. H. and Norman, A. W. (1995) Endocr. Rev. 16, 200-257

13 DeLuca, H. F. and Zierold, C. (1998) Nutr. Rev. 56, S4-S10

14 Björkhem, I. and Boberg, K. M. (1995) in The Metabolic Basis of Inherited Disease (Scriver, C. R., Beaudet, A. L., Sly, W. S. and Valle, D., eds.), pp. 2073-2099, McGraw-Hill Inc., New York

15 Cali, J. J., Hsieh, C. L., Francke, U. and Russell, D. W. (1991) J. Biol. Chem. 266, 7779-7783

16 Leitersdorf, E., Reshef, A., Meiner, V., Levitzki, R., Pressman Schwartz, S., Klapholz, L., Berkman, N., Cali, J. J., Klapholz, L. and Berginer, V. M. (1993) J. Clin. Invest. 91, 2488-2496

17 Berginer, V. M., Shany, S., Alkalay, D., Berginer, J., Dekel, S., Salen, G., Tint, G. S. and Gazit, D. (1992) Metab. Clin. Exp. 42, 69-74

18 Lund, E., Björkhem, I., Furster, C. and Wikvall, K. (1993) Biochim. Biophys. Acta 1166, 177-182

19 Saucier, S.E., Kandutsch, A. A., Gayen, A. K., Swahn, D. K. and Spencer, T. A. (1989) J. Biol. Chem. 264, 6863-6869

20 Janowski, B. A., Willy, P. J., Devi, T. R., Falck, J. R. and Mangelsdorf, D. J. (1996) Nature (London) 383, 728-731

21 Janowski, B. A., Grogan, M. J., Jones, S. A., Wisely, G. B., Kliewer, S. A., Corey, E. J. and Mangelsdorf, D. J. (1999) Proc. Natl. Acad. Sci. U.S.A. 96, 266-271

22 Christenson, L. K., McAllister, J. M., Martin, K. 0., Javitt, N. B., Osborne, T. F. and Strauss, III, J. F. (1998) J. Biol. Chem. 273, 30729-30735

23 Babiker, A., Andersson, O., Lund, E., Xiu, R.-J., Deeb, S., Reshef, A., Leitersdorf, E., Diczfalusy, U. and Björkhem, I. (1997) J. Biol. Chem. 272, 26253-26261

24 Postlind, H. and Wikvall, K. (1989) Biochem. Biophys. Res. Commun. 159 1135-1140

25 Postlind, H. and Wikvall, K. (1988) Biochem. J. 253, 549-552

26 Bergman, T. and Postlind, H. (1991) Biochem. J. 276, 427-432

27 Sambrook, J., Fritsch, E. F. and Maniatis, T. (1989) Molecular Cloning: A Laboratory Manual, 2nd edn., Cold Spring Harbor Laboratory Press, Cold Spring Harbor, NY

28 Wikvall, K. (1984) J. Biol. Chem. 259, 3800-3804

29 Tuls, J., Geren, L. and Millett, F. (1989) J. Biol. Chem. 264, 16421-16425

30 Holick, M. F. (1994) in The Liver: Biology and Pathobiology, 3rd edn. (Araias, I. M., Boyer, J. L., Fausto, N., Jakoby, W. B., Schachter, D. A. and Shafritz, D. A., eds.) pp. 543-562, Raven Press, New York

31 Henry, H. L. (1992) J. Cell. Biochem. 49, 4-9

32 Tucker, III, G., Gagnon, R. E. and Haussler, R. M. (1973) Arch. Biochem. Biophys. 155, $47-57$

33 Olson, Jr., E. B., Knutson, J. C., Bhattacharyya, M. H. and DeLuca, H. F. (1976) J. Clin. Invest. 57, 1213-1220

34 Krawitt, E. L., Grundman, M. J. and Mawer, B. E. (1977) Lancet ii, 1246-1249

35 Holmes, R. P. and Kummerow, F. A. (1983) J. Am. Coll. Nutr. 2, 173-199

36 Takeyama, K., Kitanaka, S., Sato, T., Kobori, M., Yanagisawa, J. and Kato, S. (1997) Science 277, 1827-1830

37 St-Arnaud, R., Messerlian, S., Moir, J. M., Omdahl, J. L. and Glorieux, F. H. (1997) J. Bone Miner. Res. 12, 1552-1559

38 Monkawa, T., Yoshida, T., Wakino, S., Shinki, T., Anazawa, H., DeLuca, H. F., Suda, T., Hayashi, M. and Saruta, T. (1997) Biochem. Biophys. Res. Commun. 239, 527-533

39 Fu, G. K., Lin, D., Zhang, M. Y. H., Bikle, D. D., Shackleton, C. H. L., Miller, W. L. and Portale, A. A. (1997) Mol. Endocrinol. 11, 1961-1970

40 Axén, E. (1995) FEBS Lett. 375, 277-279

41 Rosen, H., Reshef, A., Maeda, N., Lippoldt, A., Shpizen, S., Triger, L., Eggertsen, G., Björkhem, I. and Leitersdorf, E. (1998) J. Biol. Chem. 273, 14805-14812

42 Okuda, K.-I., Usui, E. and Ohyama, Y. (1995) J. Lipid Res. 36, 1641-1652

43 Postlind, H., Axén, E., Bergman, T. and Wikvall, K. (1997) Biochem. Biophys. Res. Commun. 241, 491-497

44 Axén, E., Harmeyer, J. and Wikvall, K. (1998) Biochim. Biophys. Acta 1407 234-242

45 Araya, Z., Norlin, M. and Postlind, H. (1996) FEBS Lett. 390, 10-14

46 Martin, K. O., Reiss, A. B., Lathe, R. and Javitt, N. B. (1997) J. Lipid Res. 38, 1053-1058

47 Axelson, M. and Larsson, 0. (1995) J. Biol. Chem. 270, 15102-15110

48 Schwartz, M., Lund, E. G., Lathe, R., Björkhem, I. and Russell, D. W. (1997) J. Biol. Chem. 272, 23995-24001

49 Pedersen, J. I., Eggertsen, G., Hellman, U., Andersson, U. and Björkhem, I. (1997) J. Biol. Chem. 272, 18481-18489

50 Kwakye, J. B., Barnes, S. and Diasio, R. B. (1993) J. Lipid Res. 34, 95-99

51 Kwakye, J. B., Johnson, M. R., Barnes, S., Grizzle, W. E. and Diasio, R. B. (1991) Biochem. J. 280, 821-824

Received 13 September 1999/18 January 2000; accepted 9 February 2000 